\title{
内科勤務医の仕事満足度，メンタルヘルス， 就労環境における男女差
}

\section{小崪 真規子 早野 恵子 徳田 安春尾藤 誠司}

\section{要約}

【目的】女性内科医の仕事満足度やメンタルヘルス, 就労環境など医師としての職業生活について 記述し，男性のそれと比較検討する。

【方法】内科勤務医を対象に郵送法による自記式質問紙票調査を行った．調査票は仕事満足度，外 来診察時間，就労環境等の質問項目を含み，これらについて男女間で比較した。

【結果】 234 名を解析対象とした (女性:59 名)。女性医師は男性医師に比べ一人の患者にかける診 察時間が長かった (初診 $P<0.01$, 再診 $P=0.046$ )。当直時には女性医師も男性医師と同程度の連 続勤務についていたが ( 平均 31.1 時間 ), 質を維持できると考える最長の連続勤務時間 ( 限界連続 勤務時間 ) について，女性医師は男性医師より有意に短く回答した (-4 時間, $P=0.02)$.

【結論】女性医師は男性医師より患者あたりの診察時間が長く, 限界連続勤務時間が短かつた.

Key Words:

女性医師, 就労環境, メンタルヘルス

〔日本プライマリ・ケア連合学会誌２010,vol.33,no.4,p. 369 - 377〕

\section{緒 言}

女性の社会進出に伴い，医師に占める女性の割合は $17.2 \%$ 〔平成 18(2006) 年〕, 医師国家試験合格者に占 める女性の割合は 34.5\%〔平成 20(2008) 年〕と増加し ている．近年の深刻な医師不足を背景に，女性医師の 積極的な活用が議論されているが，今までのところ家 庭生活とのバランスをどのように支援するかというこ とが議論の中心になっている ${ }^{1-3)}$.

一方で, 日本より早く女性医師の増加を経験した欧 米では，医師という職業生活においても，男女で就労 環境や仕事満足度, メンタルヘルスなど, 異なる点が
あることが指摘されている，例えば，米国における大 規模な調查では, 女性医師の方が職場における裁量度 が低く, 収入が少なく, バーンアウトが多いというこ とが明らかになっている ${ }^{4)}$. また，診療パターンに関 $し て$, 女性医師は男性医師より予防医療に力正入れる こと，そのため出来高制の評価では低く評価されがち になるということが指摘されている ${ }^{4)}$.これに対して 日本では, 女性医師の診療スタイル, 就労環境, 仕事 満足度やメンタルヘルスを含めた職業生活が, 男性の それと異なるのか，もし異なるとすればどのような点

小謧真規子 堀川病院内科

早野恵子 済生会熊本病院総合診療科

徳田安春 筑波大学附属病院水戸地域医療教育センター

尾藤誠司 国立病院機構東京医療センター臨床研究センター臨床疫学室

著者連絡先:

小㠃真規子 (おざきまきこ)

堀川病院 内科

( ₹ 602-0056 京都市上京区堀川通今出川上る北舟橋町 865 E,mail : mmozaki@yahoo.co.jp)

受付日： 2010 年 5 月 7 日, 受理日：2010 年 10 月 7 日 
が男性のそれと異なるのかということについての知見 は不足している。

現状の，特に勤務医の過酷な労働環境を鑑みて，適 切な労働環境を整備し, 男女問わず家庭生活との両立 支援を行うことは必然であるが，それに加えて医師と いう職業生活における男女の特性および相違点を理解 し，それぞれにとって適切な支援を行うことが必要で ある。

本研究の目的は, 女性内科医の仕事満足度やメンタ ルヘルス, 就労環境など医師としての職業生活につい て記述し，男性のそれと比較検討することである。

\section{対象および方法}

2007 年 9 月に, 無記名自記式質問紙票による「勤 務医の就労環境と就労意識に関する調査」を，郵送法 にて行った ${ }^{5)}$. 対象母集団として病院に勤務する内科 医を設定し，内科系，プライマリ・ケア系の複数の医 師メーリングリストで調査への参加募集を行った。呼 びかけに答えた医師に対し自己記入式調査票を送付し た。調査票は 2 週間あけて 2 回郵送された。

\section{1 ) 測定変数}

\section{a) 仕事満足度}

仕事満足度は, 日本の病院医師を対象に開発され, 信頼性, 妥当性の検証がなされている Japan Hospital Physician Satisfaction Scale (JHPSS) を用いて测定し た ${ }^{6)}$. JHPSS は，2つの全体尺度と 6 つの下位尺度 の計 28 項目から成るが，そのうちの 2 つの全体尺度, 現状の仕事への全体的な満足度を表す「全体仕事満足 度 (Global Job Satisfaction, GJS)」と医師としてのキャ リアへの満足度「全体キャリア満足度 (Global Career Satisfaction, GCS) 」, および 1 つの下位尺度, 仕事と 報酬のバランスを考慮した収入への満足度「報酬 (Pay)」の計 10 項目を使用した. 各項目の回答選択肢は, $\lceil 1=$ 全くそうは思わない」, $2=$ そうは思わない」, 「3= どちらともいえない」,「4=そう思う」,「5＝非常に そう思う」の 5 段階 Likert法とし，それぞれ合計し 0 〜 100 点に換算して用い, 得点が高いほど満足度が高 い状態を表す。

\section{b) バーンアウト}

バーンアウトの測定には，使用頻度が高く信頼性妥 当性の確立された Maslach Burnout Inventory (MBI) 7)の日本語版 ${ }^{8)}$ を用いた. MBI は 22 項目から成り, 各質問項目に対しどの程度の頻度で遭遇するか, 0 〜
6 の 7 段階で回答する.MBI は, 情緒的疲弊 (emotional exhaustion, EE)，脱人格化 (depersonalization, DP) , 個人的達成感 (personal accomplishment, PA) の 3 つ の下位尺度を持ち, 各下位尺度得点は素点の合計で求 められ, EE, DP は点数が高いほど, PA は点数が低 いほどバーンアウトの高い状態とされる。 $\mathrm{EE} か ゙ 27$ 点以上を高 $\mathrm{EE}$ 群, $\mathrm{DP}$ が 10 点以上を高 $\mathrm{DP}$ 群とし9, 10), 高 $\mathrm{EE}$ 群または高 DP 群をバーンアウト (状態) と 定義した ${ }^{9,11,12)}$. 今回, PA は精神的・肉体的ストレ スとの関連が低く先行研究でも用いられないことが多 いため解析には使用しなかった ${ }^{9}$.

\section{c) 仕事のコントロール度}

仕事量に関して，医師自身がどの程度コントロール できるかということに注目した，先行研究を元に，仕 事量のコントロールに関する6つの質問 (事務仕事の 量, 勤務時間, 予定外の仕事, 患者数, 設備, 仕事の ペース)を用意し，それぞれについて回答選択肢は， $\lceil 1=$ ほとど出来ない」, 「 $2=$ 少し出来る」, 「 $3=$ あ る程度出来る」,「4=かなり出来る」の 4 段階 Likert 法とした ${ }^{13)}$. 得点は 6 項目を合計し 0 〜 100 点に換 算して用い，得点が高いほど自分でコントロールでき る程度が大きいことを表す。

使用した尺度の信頼性に関しては，上記 GJS， GCS, PAY, EE，DP，仕事のコントロール度尺度 項目の Cronbach' s $a$ 係数は, 0.83, 0.69, 0.78, 0.89, $0.77,0.83$ であり満足できるものであった.

\section{d) 就労環境}

平均的な週労働時間，およびその内訳，一ヶ月の平 均当直回数, 平均的な連続勤務時間などを尋ねた。連 続勤務時間については，当直等を挟んだ平均的な連続 勤務時間，および自身が提供する医療の質を維持でき ると考える最長の連続勤務時間 (限界連続勤務時間) を尋ねた。

\section{e) 外来診察時間}

初診，再診外来において一患者あたりの診察に平均 して何分かけているか，および，質の高い医療を提供 するためには一患者あたりどのくらいの時間が必要と 感じるかを尋ねた。

医師の性別, 年齢, 専門 (臟器別内科専門医 vs. 一 般内科 / 総合診療 /プライマリ・ケア $(\mathrm{PC} / \mathrm{GIM}))$, 勤 


\section{表 1 回答者特性}

\begin{tabular}{lccc}
\hline & $\begin{array}{c}\text { 女性医師 } \\
\mathrm{n}=59\end{array}$ & $\begin{array}{c}\text { 男性医師 } \\
\mathrm{n}=175\end{array}$ & $\mathrm{P}$ 值 \\
\hline 平均年齢(SD) & $38.0(6.7)$ & $41.7(8.0)$ & $<0.01$ \\
婚姻状況 & & & $<0.01$ \\
既婚, \% & 47.5 & 86.2 & \\
独身, \% & 45.8 & 12.1 & \\
離婚·死別, \% & 6.8 & 1.7 & \\
同居の子あり, \% & 33.9 & 69.1 & $<0.01$ \\
同居の親あり, \% & 22 & 9.1 & $<0.01$ \\
専門, \% & & & 0.98 \\
臟器別専門医 & 67.8 & 68 & \\
PC/GIM & 32.2 & 32 & \\
常勤, \% & 79.7 & 92.0 & $<0.01$ \\
平均週労働時間(時間, SD) & $53.4(16.0)$ & $59.8(13.3)$ & $<0.01$ \\
外来診療, \% & 32.8 & 24.7 & \\
入院診療, \% & 26.4 & 31.1 & \\
診療関連, \% & 19.7 & 19.3 & \\
教育研究, \% & 12.5 & 13.2 & \\
その他, \% & 8.3 & 11.6 & \\
月平均当直回数 & 1.7 & 2.8 & $<0.01$ \\
\hline
\end{tabular}

PC/GIM: 一般内科 / 総合診療 / プライマリ・ケア

務形態 (常勤 VS. 非常勤), 婚姻状況, 年収 (税込) 等 もあわせて尋ねた。

\section{2) 解析}

一般特性や就労環境に関する単解析に際しては, t 検定， $\chi^{2}$ 検定またはFisherの直接法を用いた。 JHPSS，仕事のコントロール度について平均值にて二 群に分け，上位群を「満足している(あるいは，コン トロール度が高い)」, 下位群を「満足していない( ントロール度が低い)」とした。年齢，専門，勤務形 態で調整し，「満足している(あるいは，コントロー ル度が高い)」を従属変数としてロジスティック回帰 分析を行った。 バーンアウトに関しては，年齢，専門， 勤務形態，労働時間，当直回数，婚姻状況，同居の子 の有無を調整してロジスティック回帰分析を行った。 就労環境, 診察時間についての比較では, 年齢, 専門, 勤務形態などを調整し，重回帰分析を行った。全ての 解析は SPSS 15.0J for Windows で行い, $\mathrm{P}<0.05$ を有 意とした。

\section{3) 倫理的配慮}

本研究の実施に際しては熊本大学医学部倫理委員会 の承認を得た。メーリングリストでの参加募集の際に は，調査目的，個人情報の保護，およびデータの匿名 性について記載した。対象者の調査票の郵送時にも同 様に, 調査目的, 個人情報の保護，およびデータの匿 名性について説明した文書を同封し，調査への同意は 調査票の返信でもって同意が得られたものとした。対 象者の個人情報は第三者機関 (データセンター) が管 理し，研究者が個人を同定できないようにした。調査 票の発送，回収はデータセンターが行った。調査票回 収後,これらの個人情報は破棄された。

\section{結 果}

質問紙票は 336 名の医師に送付され，236 名 (回収 率 70.2\%) から回答を得た。そのうち調査時点では内 科医ではない2 名を除外した 234 名を解析対象とし た。 234 名の内科勤務医のうち，25.2\% (59 名) が女性 であった。回答者の平均年齢は 40.8 歳 (26-67 歳, SD: $7.8)$ で，臨床経験年数は平均 15.8 年 (3-42 年, SD: 7.3) 
表 2 医師特性別の連続勤務時間と, 質を維持できると考える連続勤務時間の限界

\begin{tabular}{|c|c|c|c|c|c|c|}
\hline & \multicolumn{3}{|c|}{ 実際の連続勤務時間(時間) } & \multicolumn{3}{|c|}{ 質を維持できる連続勤務の限界(時間) } \\
\hline & $\begin{array}{c}\text { 女性医師 } \\
n=50\end{array}$ & $\begin{array}{c}\text { 男性医師 } \\
n=165\end{array}$ & $\mathrm{P}$ 值 & $\begin{array}{c}\text { 女性医師 } \\
n=50\end{array}$ & $\begin{array}{c}\text { 男性医師 } \\
n=165\end{array}$ & $\mathrm{P}$ 值 \\
\hline 平均 & 29 & 32 & 0.12 & 16 & 20 & $<0.01$ \\
\hline \multicolumn{7}{|l|}{ 専門 } \\
\hline 臟器別専門 & 32 & 33 & 0.38 & 15 & 21 & $<0.01$ \\
\hline $\mathrm{PC} / \mathrm{GIM}$ & 21 & 29 & 0.04 & 19 & 20 & 0.70 \\
\hline \multicolumn{7}{|l|}{ 年齢 } \\
\hline 35 歳未満 & 30 & 33 & 0.29 & 19 & 21 & 0.47 \\
\hline $35-44$ 歳 & 30 & 33 & 0.27 & 15 & 20 & 0.01 \\
\hline 45 歳以上 & 21 & 29 & 0.07 & 12 & 20 & $<0.01$ \\
\hline
\end{tabular}

PC/GIM: 一般内科 / 総合診療 /プライマリ・ケア

であった，既婚者の割合は女性で有意に低く，同様に 女性では子供との同居も少なかった (表1).

\section{1) 就労環境}

234 名の回答者のうち，32.1\% (75 名) が一般内科医 であった (表 1). 一週間の勤務時間は男性の方が長く, これは，年齢，専門，勤務形態，同居の子の有無，婚 姻状況で調整しても有意であった $(\mathrm{p}<0.01)$. 勤務時間 のうち，女性は男性に比べ外来診療に費やす時間の割 合が高く, 入院診療に費や寸時間の割合は低かった. 診療関連の仕事，あるいは教育や研究に費やす時間の 割合には男女差を認めないものの, 女性は診療以外の 管理業務や会議に費やす時間の割合が低かった (表 $1)$.

1 ケ月あたりの当直回数について, 年齢, 専門, 勤 務形態，同居の子の有無，婚姻状況で調整しても女性 の方が有意に少なかった $(\mathrm{P}<0.01)$. 当直中の平均睡眠 時間は女性で 2.7 時間，男性 3.4 時間と女性で短かっ たが，年齢，専門を調整すると有意差を認めなかった $(\mathrm{P}=0.10)$.

当直時などの連続勤務時間の平均は 31.1 (SD 10.4) 時間で，提供する医療の質を維持できると考える最長 の連続勤務時間 ( 限界連続勤務時間 ) は, 男女とも実 際の連続勤務時間より短く ( 表 2), 実際の連続勤務時 間との間に男性で 12 時間，女性で 13 時間の乘離を認 めた。また，限界連続勤務時間は男性より女性の方が 平均 4 時間短く, これは年齢, 専門で調整しても有意 であった $(\mathrm{P}=0.02)$.

年収 (税込み) は女性では男性に比して, 平均して 約 320 万円少なかった。年齢, 専門, 勤務形態, 労働
時間, 当直回数, 現職年数, 婚姻状況を調整しても, 女性の方が有意に低かった ( 約 180 万円. $\mathrm{P}=0.02$ ).

\section{2) 仕事満足度, バーンアウト, 仕事のコントロール 度}

仕事満足度に関して，全体として現状での仕事満足 度 (GJS), 医師というキャリアへの満足度 (GCS), 報 酬についての満足度 (PAY)の平均值は, 女性医師で 59.0，54.9，47.0，男性医師では 58.5，54.0，50.3 と中 等度であった。報酬についての満足度 (PAY) は年齢, 専門, 勤務形態で調整しても女性医師の方が低かった (表 3). バーンアウトは女性医師の $50.8 \%$, 男性医師 の $40.0 \%$ に認めたが，年齢，専門，労働時間，当直回 数, 婚姻状況, 同居の子の有無で調整すると有意な差 を認めなかった (表 3 ). 仕事のコントロール度は女性 医師の方が低い傾向を認めたが有意ではなかった (表 $3)$.

\section{3) 診察時間}

一人の患者の診察に，女性医師は平均して初診では 21 分, 通常の再診では 9 分かけるが, 男性医師の場 合はそれぞれ 16 分と 7 分であった (表 4). これは, 初診, 再診時間とも年齢, 専門で調整しても, 女性医 師のほうが有意に長かった ( 初診 $\mathrm{P}<0.01$, 再診 $\mathrm{P}=0.046)$. また，良質な医療を提供するために必要と 感じる一患者当たりの診察時間も, 女性医師の方が男 性医師より初診, 再診とも長く (表4), 同様に調整し ても初診, 再診とも女性のほうが有意に長かった(初 診 $: P=0.03$, 再診 $: P<0.01)$. 
表 3 男性医師と比較した女性医師の仕事満足度 ${ }^{*}$, 仕事のコントロール度 *, バーンアウト ${ }^{\dagger}$

\begin{tabular}{lccc}
\hline & オッズ比 & \multicolumn{2}{c}{$95 \% \mathrm{CI}$} \\
\hline 仕事満足度 & & & \\
全体仕事満足度 (GJS) & 1.04 & $0.56-1.94$ \\
全体キャリア満足度 (GCS) & 1.68 & $0.89-3.15$ \\
報酬についての満足度 (PAY) & 0.49 & $0.25-0.98$ \\
仕事のコントロール度 & 1.04 & $0.55-1.97$ \\
バーンアウト & 1.57 & $0.75-3.33$ \\
\hline
\end{tabular}

* 年齢, 専門, 勤務形態で調整. 得点の下位群に対する上位群のオッズ比.

$\dagger$ 年齢, 専門, 勤務形態, 労働時間, 当直回数, 婚姻状況, 同居の子の有無で調整.

\section{考 察}

近年, 女性医師の積極的な活用が議論されているが， 今回，内科勤務医の職業生活において，男性医師とは 異なる女性医師の特性が明らかになった。

\section{1) 限界連続勤務時間}

当直を挟んだ連続勤務時間は平均 31 時間と男女と も長く, うち $20 \%$ が平均して 36 時間以上の連続勤務 を行っていた。実際の連続勤務時間と，医師自身が質 を保てると考える限界連続勤務との間に平均 11.3 時 間の乘離を認めており，医師は男女問わず自らが提供 する医療の安全・質に不安を持ちながら当直勤務に就 いているということが推察される。今回，女性医師は 男性に比して限界連続勤務時間を有意に短く回答して いるが，これには睡眠不足の影響が男女で異なること が背景にある可能性がある。睡眠が不足した場合，女 性の方が男性より主観的健康感の低下が著しく，イラ イラや抑うつなど精神的不調が多くみられることが指 摘されている ${ }^{14,15)}$. 医師職においても，女性医師では 睡眠時間と仕事満足度との間に関連を認める一方で, 男性医師ではそのような関連は認めないこと5)，女性 医師では当直と抑うつとの間に関連を認めることが指 摘されている ${ }^{16)}$.

近年，女性医師活用のために院内に 24 時間保育所 を整備し ${ }^{17}$ ，子供を持つ女性医師でも当直業務に就き やすくしようとする取り組みが行われているが，上述 のように睡眠不足の影響が男性より大きく，質を保て ると感じる連続勤務時間が男性より短い女性医師に とっては，適切な勤務時間のシフト制の方が参加しゃ すい可能性がある。また，今回，当直中の睡眠時間に ついては男女とも約 3 時間であったが，5時間未満の 睡眠では精神活動が低下しパフォーマンスが著しく低

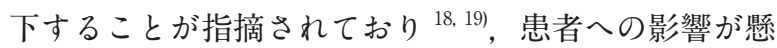

念される。加えて, 医師の約 9 割は当直翌日も通常勤 務に就いており ${ }^{20)}$ ，このような医療者の長時間勤務は 患者の安全にとっても ${ }^{18,21,22)}$, 医師自身の身体的, 精 神的健康にとっても有害であることは以前より指摘さ れており ${ }^{23)}$ ，医師，患者双方にとってシフト制の積極 的な導入が望ましい可能性がある。

\section{2) 収入}

収入は女性医師で有意に低かったが，若い世代 (卒 後 10 年以下) においては性別による有意な差は認め なかった $(\mathrm{P}=0.97)$. 卒後 11 年以上においては, 年齢, 専門, 勤務形態, 労働時間, 当直回数, 現職年数等を 調整しても男性に比して女性で有意に年収は低かっ た.これは,米国における先行研究の結果と同様であっ た ${ }^{4)}$. 女性医師の収入が男性より少ない理由としては, 男性に比して女性では昇進の機会が少ないため役職に 伴う手当が少ない, 待遇についての交渉スキルが未熟, 当直や残業の免除にともなう給与面での不利な待遇の 存在，などが指摘されている ${ }^{4)}$. 今回はこれらに関す る情報は入手されなかったが，本邦の医師職において も役職者に占める女性の割合は低いことは知られてお $\eta^{24,25)}$, このことが収入の男女差に影響している可能 性はある。一般に本邦では，医師職における給与の男 女差について医師自身においてもあまり認識されてい

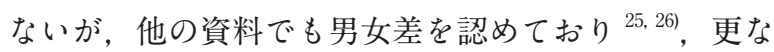
る知見の蓄積が必要である。

\section{3) 仕事満足度, バーンアウト, 仕事コントロール度}

本研究では, 先行研究と同様に, 現在の仕事に対寸 る全体的な仕事満足度に関しては男女差を認めなかっ た ${ }^{4,277}$. 医師のバーンアウトに関して本邦における報 告は少ないが，最近の井奈波らの報告では，男性内科 勤務医の約 $42 \%$ がバーンアウト状態とされており, 
今回の結果と似通っていた ${ }^{28}$ 。この報告では, 男性医 師のみを対象としており女性医師のバーンアウトの割 合は不明だが, 他の先行研究では女性医師の方がバー ンアウトの割合が高いとする報告があり ${ }^{4,29)}$, 本研究 でも有意差は認めないものの女性医師の方がバーンア ウトの割合が高かった．医師のバーンアウトは，離職 の原因になるだけでなく ${ }^{30}$ ，医療安全にとってもリス クであることが指摘されており ${ }^{31}$ ，内科勤務医の $40-$ $50 \%$ がバーンアウト状態にあるということは，医療 提供側, 医療受給側, 双方にとって危険な状態であり, 適切な対応が必要である。

最近の研究から, バーンアウトは個人的な要因より 過重労働や仕事のコントロール (裁量) の欠如, 低い 仕事のサポート (社会的支援) 等の心理社会的労働環 境要因と関連することが指摘されている ${ }^{32}$. 今回, 仕 事のコントロール度は女性医師の方が低いものの他要 因で調整すると男女差を認めなかったが, 先行研究と 同様に，女性においては仕事のコントロール度の低さ がバーンアウトのリスクとなっていた $(\mathrm{P}=0.04)^{4)}$. 男 性医師と女性医師では，バーンアウトと関連する要因 や関連の度合いが異なる可能性があり, 今後も医師を 対象にした調查が必要である。バーンアウトを防ぐた めには, 勤務医の性別に関わりなく職場の心理社会的 な環境要因を改善するための支援が必要であり, 特に, 仕事のコントロール度が低くなりがちな若年者, 非正 規職員, 低い職位の医師には積極的に支援を行う必要 があるだろう。

\section{4) 外来診察時間}

初診, 再診にかかわらず, 女性医師は男性医師より 良質な医療を提供するために必要と考える診察時間が 長く,害際に一人の患者に当てる診察時間も長かった. 女性医師の方が男性医師より診察時間が長いこと は，医師の性別とコミュニケーションに関するメタア ナリシスにおいても指摘されている ${ }^{33)}$ ここのメタアナ リシスでは，女性医師の方が患者中心のコミュニケー ションスタイルであり，女性医師に通院している患者 の方が男性医師の患者に比へ，医学的・心理社会的問 題についてよく話し，医師に対する評価も肯定的であ ることも指摘されている ${ }^{33}$. 一方で, 女性医師の方が 一人の患者にかける時間が長いということは, 単位時 間あたりに診ることのできる患者数が男性医師に比べ て少なくなる可能性があることから, 収益や診察人数 の多萓を重視する評価においては，女性医師は低く評 価される懸念があることも指摘されている ${ }^{4}$. 本邦の
医療機関でも医師職の年俸制, 業績評価の導入が進ん でいるが，これらの評価システムにおいて，女性医師 では一患者あたりの診察時間が長いという特性が，女 性医師の評価に影響を与えているかどうかは不明であ る.

本研究の限界として以下が挙げられる. 本研究の参 加者は複数の医師メーリングリストによる呼びかけに 応じた内科勤務医だが，当該メーリングリストへの正 確な登録者数やその男女比に関するデータは入手でき なかった。また，調査票への非回答者の特性に関する 情報は得られていない。調查に参加した医師はもとも と就労環境やメンタルヘルスに関心の高い医師だった 可能性はある。このように, 対象者の選択においてバ イアスの生じた可能性はある. 今回, 回答者に占める 女性医師の割合 (25.2\%) は勤務医を対象とした先行研 究における女性医師の割合 $(13.4-16.0 \%){ }^{20.34)}$ や，内 科勤務医に占める女性医師の割合 (18.1\%) 上り高かっ たが ${ }^{35)}$ ，女性医師のサンプル数は比較的少数であった ため結果の一般化には注意が必要である。診察時間等 については自己申告を元にしており，実際にかかって いる診察時間を正確に反映していない可能性がある.

以上の上うな限界はあるものの本研究の対象者の週 労働時間, 当直回数など労働条件は, 他の報告と似通っ ており ${ }^{20,34)}$ ，一定の範囲において新たな知見を提供す るものと考えられる。

\section{結 論}

女性の内科勤務医は, 男性の同僚医師と比べ, 就労 状況，良質な医療を提供できると考える最長の連続勤 務時間, 収入および収入への満足度, 一患者あたり外 来診察時間に関して違いを認めたが, 現状での仕事に ついては全体的に男性と同程度に満足していた。

昨今の病院医療の現場では，医師不足を背景に女性 医師のより積極的な参加が期待されている。しかしそ のためには, 女性医師が満足して参加し, 継続しやす いシステムが必要である。特に, 長時間連続勤務に対 する男女の意識の相違については考慮すべき問題であ 万う。

現状の病院勤務医を取り巻くシステムは, 女性医師 の特性を考虑せずに築き上げられてきたが，今後は男 性医師とは異なる特性を持つ女性医師という存在も念 頭において再構築していく必要がある。そのためには, 医師職における男女の特性に注目した研究を積極的に 行い, 基礎となる知見を集積していく必要がある. 


\section{表 4 医師特性別, 一患者あたりの平均外来診察時間 ( 実際の診察時間 ) および良質な医療を提供するために必要と 考える診察時間 ( 必要な診察時間 )}

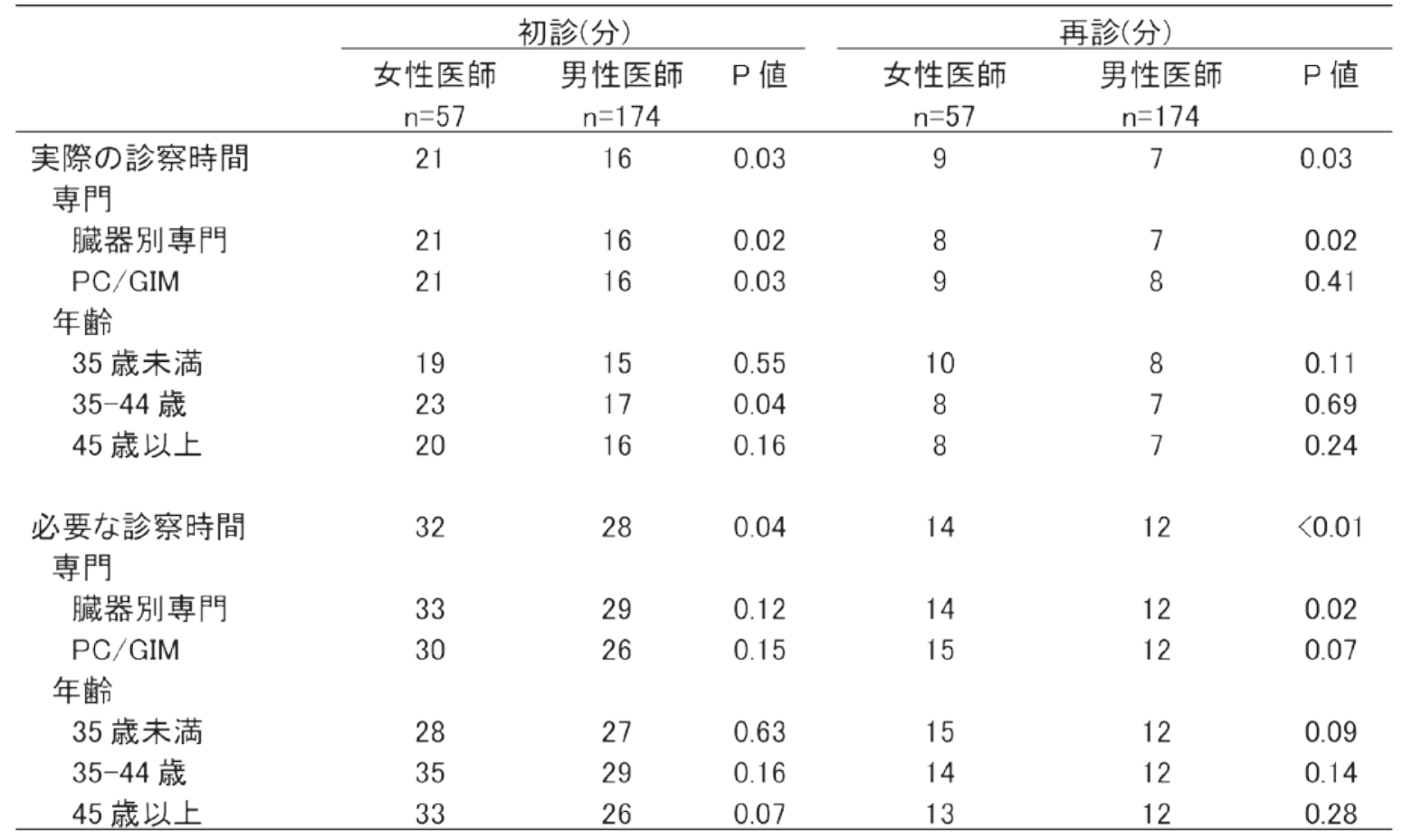

PC/GIM: 一般内科 / 総合診療 /プライマリ・ケア

\section{謝 辞}

本研究は文部科学研究費補助金 (研究課題名 : わが 国における医師のプロフェッショナリズム探索と推 進・教育に関する事業研究：課題番号 18390165)の 一部として実施された。本研究にご協力下さった内科 勤務医の皆様に深謝致します。

\section{文 献}

1) 川上順子。女性医師を取り巻く諸問題と対策につい て (東京女子医科大学におけるモデルケース). 日本の 眼科. 2009, vol.80,p. 839-842.

2) 池田美智子.女性医師の仕事と家庭 (育児) の両立 支援。日本小児科医会会報。2006,p.184-185.

3) 法井薰, 他. 福島県立医科大学における女性医師の ワーク・ライフ・バランスに関する現状. 福島医学雑誌. 2007,vol.57, p.107-113.

4) McMurray, J.E.et al. The work lives of women physicians results from the physician work life study. The SGIM Career Satisfaction Study Group. J Gen Intern Med. 2000,vol.15, p.372-380.

5) Tokuda, Y. et al. The interrelationships between working conditions, job satisfaction, burnout and mental health among hospital physicians in Japan: a path analysis. Ind Health. 2009,vol.47, p.166-172.

6) Ozaki ,M. et al. Development of the Japan Hospital Physician Satisfaction Scale. Int J Health Care Qual Assur. 2008,vol.21, p.517-528.

7) Maslach, C. et al. The measurement of experienced burnout. . Journal of Occupational Behaviour. 1981,vol.2,p. 99-113.

8) 東口和代, 他。日本版 MBI(Maslach Burnout Inventory) の作成と因子構造の検討. 日本衛生学雑誌. 1998,vol.53, p.447-455.

9) Maslach ,C.et al. Maslach Burnout Inventory Manual. 3rd ed. Palo Alto, Calif: Consulting Psychology Press, 1986.

10) Thomas, N.K. Resident burnout. JAMA. 2004,vol.292, p.2880-2889.

11) Brenninkmeijer, V.et al. How to conduct research on burnout: advantages and disadvantages of a unidimensional approach in burnout research. Occup Environ Med. 2003,vol.60 Suppl 1, i16-20.

12) Rafferty, J.P. et al. Validity of the Maslach Burnout Inventory for family practice physicians. J 
Clin Psychol. 1986,vol.42, 488-492.

13) 小謧真規子, 他. 病院勤務医の仕事満足度と職場異 動希望および臨床からの離脱希望。日本医療・病院管 理学会誌. 2008,vol.45, p.115-122.

14) Birchler-Pedross ,A. et al. Subjective well-being is modulated by circadian phase, sleep pressure, age, and gender. J Biol Rhythms. 2009,vol.24, p.232-242.

15) Gay, C.L. et al. Sleep patterns and fatigue in new mothers and fathers. Biol Res Nurs. 2004,vol.5, p.311318.

16) Hayasaka,Y,.et al. Work environment and mental health status assessed by the general health questionnaire in female Japanese doctors. Industrial Health. 2007,vol.45, p.781-786.

17）厚生労働省. 緊急医師確保対策. http://www. mhlw.go.jp/topics/bukyoku/isei/kinkyu/dl/01c.pdf. ( 参照 2010.9.1)

18) Lamberg, L. Long hours, little sleep: bad medicine for physicians-in-training? Jama. 2002,vol.287, p.303306.

19) Dinges, D.F.et al. Cumulative sleepiness, mood disturbance, and psychomotor vigilance performance decrements during a week of sleep restricted to $4-5$ hours per night. Sleep. 1997,vol.20, p.267-277.

20）日本病院会. 医師確保に係る調查報告書 勤務医に 関する意識調查報告書 . http://www.mhlw.go.jp/ shingi/2007/04/dl/s0410-4b.pdf. (参照 2010.9.1)

21) Landrigan, C.P. et al. Effect of reducing interns' work hours on serious medical errors in intensive care units. N Engl J Med. 2004,vol.351, p.1838-1848.

22) Lockley ,S.W,.et al. Effects of health care provider work hours and sleep deprivation on safety and performance. Jt Comm J Qual Patient Saf. 2007,vol.33, p.7-18.

23) 富田絵梨子, 他. 週 80 時間労働が研修医のストレ 又構造に与える影響. 産業衛生学雑誌. 2007,H104.

24) 王置 (橋本) 知子. 文部科学省科学技術振興調整費 「女性研究者支援モデル育成」事業「保育とワークシェ アによる女性医学研究者支援プロジェクト」報告書. 女性研究者として, 医師として - 女性医師の働く環境 と働き続け - . http://ir.twmu.ac.jp/dspace/ bitstream/10470/11896/1/josei(20)154-159.pdf. (参 照 2010.9.1)

25）荒木葉子. 女性医師のワーク・ライフ・バランス の現状. 日本医療学会 市民シンポジゥム 2008. http://www.jhcs.jp/s/symposium/04/result.html. (参 照 2010.9.1)

26）厚生労働省. 平成 20 年賃金構造基本統計調查. http://www.mhlw.go.jp/toukei/list/52-20.html. ( 参照 2010.9.1)

27) Bovier, P.A. et al. Predictors of work satisfaction among physicians. Eur J Public Health. 2003,vol.13, p.299-305.

28）井奈波良一, 他. 大規模自治体病院医師の勤務状 況，日常生活習慣および職業性ストレス。日本職業・ 災害医学会会誌. 2008,vol.56,p.239-245.

29）久村正也. 医師のストレス - ストレス状況，抑う つ傾向, 燃え尽き状態の男女医差. ストレス科学. 1997,vol.2, p.61-64.

30) Borritz, M. et al. Burnout as a predictor of selfreported sickness absence among human service workers: prospective findings from three year follow up of the PUMA study. Occup Environ Med. 2006,vol.63, p.98-106.

31）北岡和代. 精神科勤務の看護者のバーンアウトと 医療事故の因果関係についての検討 . 日本看護科学会 誌. 2005,vol.25,p. 31-40.

32) Escriba-Aguir, V. et al. Psychosocial work environment and burnout among emergency medical and nursing staff. Int Arch Occup Environ Health. 2006,vol.80, p.127-33.

33) Roter,D.L,.et al. Physician gender and patientcentered communication: a critical review of empirical research. Annu Rev Public Health. 2004,vol.25, p.497-519.

34) 日本医療労働組合連合会. 医師の労働実態調査報 告 書 . http://www.irouren.or.jp/jp/html/menu6/ pdf/070424ishi_fusoku_teigen_matome.pdf. ( 参 照 2010.9.1)

35) 厚生労働省. 平成 18 年度医師調査. http://www. mhlw.go.jp/toukei/saikin/hw/ishi/06/kekkal-2-3.html ( 参照 2010.9.1) 


\title{
Abstract
}

Gender differences in job satisfaction, mental health and work environments of hospital internists in Japan.

\author{
Makiko Ozaki ${ }^{1}$, Keiko Hayano ${ }^{2}$, Yasuharu Tokuda ${ }^{3}$, Seiji Bito ${ }^{4}$ \\ ${ }^{1}$ Department of Internal Mdicine, Horikawa Hospital \\ ${ }^{2}$ Department of General Medicine, Saiseikai Kumamoto Hospital \\ ${ }^{3}$ Mito Medical Center, University of Tsukuba Hospital, Institute of Clinical Medicine, Graduate School of \\ Comprehensive Human Sciences, University of Tsukuba \\ ${ }^{4}$ Division of Clinical Epidemiology, National Hospital Organization Tokyo Medical Center
}

OBJECTIVE: To describe gender differences in job satisfaction, mental health and work conditions of Japanese hospital internists

METHODS: A self-administered, mailed survey was conducted among hospital internists throughout Japan. The survey included questions such as job satisfaction, time allotted for an ambulatory patient, and work environments.

RESULTS: Two hundred thirty-four hospital internists were eligible (59 women). Female internists allotted more time for each patient in an ambulatory care setting than their male colleagues (new patient/consultation: $\mathrm{P}<0.01$, routine follow ups: $\mathrm{P}=0.046$ ). Female internists worked continuously for as long as their male colleagues when they were on night duty (average: 31.1 hours), but their replies indicated that they were not able to maintain continuous high-quality care for as long as the male internists ( -4 hours, $\mathrm{P}=0.02)$.

CONCLUSIONS: Female internists allotted more time for each ambulatory patient, and their replies showed that they were able to maintain quality care continuously for less time than were the males. 